Originally published as:

Wittmann, H., von Blanckenburg, F. (2009): Cosmogenic nuclide budgeting of floodplain sediment transfer. - Geomorphology, 109, 3-4, 246-256

DOI: 10.1016/j.geomorph.2009.03.006 


\title{
Cosmogenic nuclide budgeting of floodplain sediment transfer
}

\author{
H. Wittmann ${ }^{*}, 1$, F. von Blanckenburg ${ }^{1}$ \\ Institut für Mineralogie, Universität Hannover, Callinstr. 3, Hannover, Germany \\ *Corresponding author. Tel.: +49 (0)331 288 2820; E-mail: wittmann@gfz-potsdam.de \\ ${ }^{1}$ Current address: Sektion 3.4, Deutsches GeoForschungsZentrum GFZ, Telegrafenberg, Potsdam, Germany
}

Published in GEOMORPHOLOGY (2009); Vol. 109, p. 246-256.

\begin{abstract}
Cosmogenic nuclides produced in quartz may either decay or accumulate while sediment is moved through a river basin. A change in nuclide concentration resulting from storage in a floodplain is potentially important in large drainage basins in which sediment is prone to repeated burial and remobilization as a river migrates through its floodplain. We have modeled depth- and time-dependent cosmogenic nuclide concentration changes for ${ }^{10} \mathrm{Be}$, ${ }^{26} \mathrm{Al}$, and ${ }^{14} \mathrm{C}$ during sediment storage and mixing in various active floodplain settings ranging from confined, shallow rivers with small floodplains to foreland-basin scale floodplains traversed by deep rivers. Floodplain storage time, estimated from channel migration rates, ranges from $0.4 \mathrm{ky}$ for the Beni River basin (Bolivia) to $7 \mathrm{ky}$ for the Amazon River basin, while floodplain storage depth, estimated from channel depth, ranges from 1 to $25 \mathrm{~m}$.
\end{abstract}

For all modeled active floodplain settings, the long-lived nuclides ${ }^{10} \mathrm{Be}$ and ${ }^{26} \mathrm{Al}$ show neither significant increase in nuclide concentration from irradiation nor decrease from decay. We predict a hypothetical response time after which changes in ${ }^{10} \mathrm{Be}$ or ${ }^{26} \mathrm{Al}$ concentrations become analytically resolvable. This interval ranges from 0.07 to 2 My and exceeds in all cases the typical residence time of sediment in a floodplain. Due to the much shorter half life of ${ }^{14} \mathrm{C}$, nuclide concentrations modeled for the in situ-produced variety of this nuclide are, however, sensitive to floodplain storage on residence times of $<20 \mathrm{ky}$.

The cosmogenic nuclide composition of old deposits in currently inactive floodplains that have been isolated for periods of millions of years from the river that once deposited them are predicted to either increase or decrease in ${ }^{10} \mathrm{Be}$ and ${ }^{26} \mathrm{Al}$ concentration, depending on the 
depositional depth. These conditions can be evaluated using the ${ }^{26} \mathrm{Al} /{ }^{10} \mathrm{Be}$ ratio that readily discloses the depth and duration of storage.

We illustrate these models with examples from the Amazon basin. As predicted, modern bedload collected from an Amazon tributary, the Bolivian Beni River, shows no systematic change in nuclide concentration as sediment is moved through $500 \mathrm{~km}$ of floodplain by river meandering. In contrast, in the central Amazon floodplain currently untouched by the modern river system, low ${ }^{26} \mathrm{Al} /{ }^{10} \mathrm{Be}$ ratios account for minimum burial depths of 5 to $10 \mathrm{~m}$ for a duration of $>5 \mathrm{My}$.

The important result of this analysis is that in all likely cases of active floodplains, cosmogenic ${ }^{10} \mathrm{Be}$ and ${ }^{26} \mathrm{Al}$ concentrations remain virtually unchanged over the interval sediment usually spends in the basin. Thus, spatially-averaged denudation rates of the sediment-producing area can be inferred throughout the entire basin, provided that nuclide production rates are scaled for the altitudes of the sediment-producing area only, because floodplain storage does not modify nuclide concentrations introduced from the sediment source area.

Keywords: Cosmogenic isotopes; Erosion rate; Sediment budget; Floodplains; Sediment transfer; Depositional basins

\section{Introduction}

Cosmogenic nuclides accumulate in minerals on hillslopes during weathering and erosion, where a denudation rate can be calculated from cosmogenic nuclide concentrations. The timescale over which this denudation rate integrates is $Z^{*} / \varepsilon$, where $z^{*}$ is the $e$-folding depth of cosmic ray absorption, typically $600 \mathrm{~mm}$. Rates therefore integrate over 1-100 ky, depending on the denudation rate $\varepsilon$ ( Lal, 1991; Bierman and Steig, 1996; von Blanckenburg, 2005). Cosmogenic nuclides may also accumulate during transport and storage of sediment in streams. However, the timescale of active bedload transport in streams is usually much shorter than that of hillslope processes (Whipple and Tucker, 1999), and moreover, sediment is shielded by water so that active bedload transport is unaffected by nuclide accumulation. During storage and shielding of sediment in floodplains however, which may encompass several thousand to even millions of years in continental-scale basins, nuclide accumulation at the floodplain surface is proportional to the sediment storage time, while at depth it is also a function of the exponentially decreasing production rate. At great depths where shielding from cosmic rays is high, nuclide concentrations decrease from radioactive decay. As a 
consequence, the prerequisites for calculating spatially-averaged denudation rates are not met in depositional basins, where the rate of nuclide production does not necessarily equal the rate at which nuclides are being exported from a basin.

In this paper we address two distinct basin settings in which storage plays an important role. 1) Dynamic floodplains. In order to resolve processes governing cosmogenic nuclide behavior during channel-floodplain interaction featuring continuous sediment storage and remobilization, we have modeled depth- and time-dependant concentration changes for longlived $\left({ }^{26} \mathrm{Al},{ }^{10} \mathrm{Be}\right)$ and shorter-lived $\left({ }^{14} \mathrm{C}\right)$ nuclides for a variety of natural fluvial settings with various sediment reworking periods and depths. These examples are the Amazon, the Mississippi, the Beni, the Rhine, the Pearl, and the Vermillion Rivers and cover the full spatial range of dynamic fluvial settings. 2) Old deposits in static floodplains. For deciphering cosmogenic nuclide changes in old floodplain deposits that are only episodically tapped by river migration and thus are prone to million-year scale storage, long-lived nuclides $\left({ }^{26} \mathrm{Al}\right.$, ${ }^{10} \mathrm{Be}$ ) and their respective ratio can be used to estimate burial depth, nuclide inheritance, and storage duration. Incorporation of such old deposits into the active stream might take place if sediment is eroded from terraces or inactive floodplain reservoirs or if the river is rerouted during channel avulsion, which is driven by tectonic faulting, high discharge events, and rapid levee build-up relative to slow lateral motion via bank erosion in depositional settings (Slingerland and Smith, 2004; Jerolmack and Mohrig, 2007).

Preliminary cosmogenic nuclide data measured in Beni River floodplain sediment will serve to illustrate the applicability of our dynamic model, while cosmogenic nuclide data from modern and old floodplain localities of the Amazon River will demonstrate the effects of old floodplain deposits.

\section{Model setup}

In our compartment-based model, sediment is eroded in the source area, obtaining a nuclide concentration $C_{\text {up }}$ in the process (see Table 1), and is introduced into the floodplain of our model at a sediment discharge rate $Q_{\text {up }}$. This sediment is then mixed with sediment eroded from the river bank (bank erosion be) with a flux $Q_{\text {be }}$ and a nuclide concentration $C_{\text {bank }}$ as the river migrates laterally by meandering, while the resulting mix is deposited as bars (bar deposition $b d$ ) with a flux $Q_{\text {bd }}$ (see Fig. 1). The model assumes steady state between sediment flux from bank erosion and bar deposition, a simplification termed quasisteady state, which is valid for most fluvial conditions (Lauer and Parker, 2008). This assumption may not be valid for short periods, but on timescales encompassed by channel belt formation from sediment 
accumulation and aggradation ( $10^{4}$ y), the vertical accretion of floodplains is counterbalanced by the lateral erosion of the exposed bank (Wolman and Leopold, 1957; Trimble, 1995; Bridge, 2003; Meade, 2007). Therefore, $Q_{\text {be }}$ equals $Q_{\text {bd }}$.

The respective nuclide concentrations and sediment fluxes are calculated as follows. We define a residence time $\Delta t$ which is defined for each river as the time necessary to meander across its channel belt by lateral river migration:

$$
\Delta t=\frac{W_{c b}}{v}
$$

where $W_{\text {cb }}$ is the channel belt width (m), and $v$ is the channel migration rate $(\mathrm{m} / \mathrm{y})$. The width of the floodplain-channel belt can be conveniently measured from topographic maps. Next, to enable modeling of nuclide concentration changes as river particles slowly move downstream by repeated cycles of entrainment and release from the floodplain, we divide our floodplain into a discrete number of compartments. Because the residence time $\Delta t$ as defined above actually describes the traversing of the river through the floodplain compartment perpendicular to the rivers' flow direction, it provides the time necessary to liberate sedimentalso called sediment liberation cycle. The total number of liberation cycles or compartments $N$ for each setting is related to the basinwide, total sediment residence time $\Delta t_{\text {cumulative: }}$ :

$$
\Delta t_{\text {cumulative }}=N \times \Delta t
$$

Obviously, the total number of cycles is not a free parameter as it links the river migration rate, channel belt width, and the total storage time of sediment in a given river setting. $\Delta t_{\text {cumulative }}$ is estimated from basinwide residence times that are measured independently using e.g., U-series methods or sediment budgets (see Table 1 and Section 3). The number of sediment liberation cycles is then calculated from combining the residence time per compartment estimated from Eq. (1) with the basinwide residence time $\Delta t_{\text {cumulative }}$ by combining Eq. 1 and 2 to:

$$
N=\frac{\Delta t_{\text {cumulative }}}{W_{c b} \times v}
$$

In order to calculate the sediment flux from bank erosion, the size of each compartment has to be defined. In this step, the total river length $l_{\text {river }}$ (see Table 1 ) is divided 


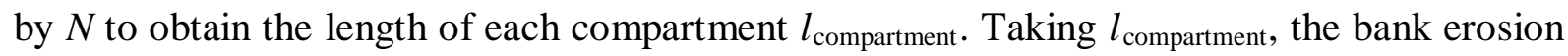
flux $Q_{\text {be }}$, equal to the bar deposition flux $Q_{\text {bd }}$, can be calculated:

$$
Q_{\text {be/bd }}=l_{\text {compartment }} \times v \times Z_{\max } \times \rho
$$

where $Z_{\max }$ is the channel depth (m), providing a minimum estimate for recently reworked floodplain depth, and $\rho$ is the wet sediment density $\left(\mathrm{g} / \mathrm{cm}^{3}\right)$. In this model system, bypassing of sediment is quantified by the ratio of the upstream sediment flux $Q_{\text {up }}$ to that of bank erosion $Q_{\text {be }}$.

The residence time $\Delta t$ of sediment in the floodplain gives the time the sediment is exposed to cosmic rays, resulting in nuclide accumulation in the river bank. The total nuclide inventory of floodplain sediment $\left(C_{\text {total }}\right)$ always contains a component inherited from erosional processes in the sediment source area $\left(C_{\mathrm{up}}\right)$ and the nuclide component generated during floodplain storage time $\Delta t\left(C_{\text {bank }}\right)$, which is calculated following Schaller et al. (2004):

$$
C_{\text {total }}=C_{u p} \times e^{(-\lambda \times \Delta t)}+C_{\text {bank }}
$$

In our model, $C_{\mathrm{up}}$ is exclusively introduced into the first compartment, where it is mixed with nuclide and sediment fluxes from bank erosion. As a consequence, $C_{\text {up }}$ is replaced by a mixture of nuclide concentrations $C_{\text {mix }}$ in all following compartments as the sediment is moved downstream, being entrained, stored and released by bank erosion for numerous cycles. $C_{\text {bank }}$ is mainly a function of the floodplain surface production rate $P_{(0)}$, the storage depth in the river bank, and cosmic ray absorption laws describing the nuclide production at depth. Nuclide production in the floodplain is calculated by scaling nuclide production at the sediment surface to sea level high latitude (SLHL), using total surface production rates of 5.53 at $/ \mathrm{g}_{(\mathrm{Qz})} / \mathrm{y}$ (Kubik et al., 1998) for ${ }^{10} \mathrm{Be}$, and a ${ }^{26} \mathrm{Al}$ production rate of $35.95 \mathrm{at} / \mathrm{g}_{(\mathrm{Qz})} / \mathrm{y}$, because the surface production ratio of ${ }^{26} \mathrm{Al} /{ }^{10} \mathrm{Be}$ is 6.5 according to Kubik et al. (1998). For a total ${ }^{14} \mathrm{C}$ production rate, we used $22.2 \mathrm{at} / \mathrm{g}_{(\mathrm{Qz})} / \mathrm{y}$ (Heisinger et al., 2002). We used the relative proportions and the depth-dependency of nuclide production by nucleons, fast muons, and stopped muons following Schaller et al. (2002). For ${ }^{14} \mathrm{C}$, we used a fast and slow muon contribution of $17 \%$ (Heisinger et al., 2002). The nuclide concentration $C_{\text {bank }}$ can then be calculated for each depth $z$ up to the maximum depth of bank erosion $z_{\max }$ by: 


$$
\begin{aligned}
& C_{\text {bank (z) }}=\left[\left(P_{\text {Nuc }}(0, i) \times \sum_{i=1}^{2} a_{i} \times e^{\frac{-z \times \rho}{b_{i}}}\right)+\left(P_{\mu s t o p p e d}(0, i) \times \sum_{j=1}^{3} a_{j} \times e^{\frac{-z \times \rho}{b_{j}}}\right)+\right. \\
&\left.\left(P_{\mu f a s t}(0, i) \times \sum_{k=1}^{3} a_{k} \times e^{\frac{-z \times \rho}{b_{k}}}\right)\right] \times \frac{1-e^{-\lambda \times \Delta t}}{\lambda}
\end{aligned}
$$

where the concentration of nuclides at a given depth $z$ is calculated for each production mode $i$ after Schaller et al. (2002). $P_{(0, \mathrm{i})}$ is the surface production rate for each nucleogenic and muonic production mechanism $i$ for ${ }^{10} \mathrm{Be}$ and ${ }^{26} \mathrm{Al}$ as parameterized by Schaller et al. (2002), using a wet floodplain sediment density of $2.0 \mathrm{~g} / \mathrm{cm}^{3}$ and a mean cosmic ray attenuation path length $\Lambda$ of $157 \mathrm{~g} / \mathrm{cm}^{2} . \lambda$ are the respective nuclides' decay constants (1/y), which were calculated using half-lives of $1.39 \mathrm{My}$ for ${ }^{10} \mathrm{Be}, 0.72 \mathrm{My}$ for ${ }^{26} \mathrm{Al}$ (Samworth et al., 1972; Chmeleff et al., 2009; Korschinek et al., 2009), and 5730 y for ${ }^{14} \mathrm{C}$ (Libby, 1955). After being stored, the sediment is released by bank erosion. Since this process results in a perfect mix of the material from all depths tapped by bank erosion, an integrated nuclide concentration $\left(C_{\operatorname{mix}(\mathrm{z})}\right)$ can be calculated by forming the average concentration over all depths (Eq. 6) from the surface to $Z_{\max }$.

The sediment produced by bank erosion is now mixed with that contained in the active channel inherited from the hinterland, which is calculated according to Eq. (5). Sediment fluxdependent mixed nuclide concentrations can then be calculated by:

$$
C_{\text {mix }}=\frac{Q_{u p} \times C_{\text {up }}+Q_{\mathrm{be}} \times C_{\text {mix }(z)}}{Q_{\text {total }}}
$$

where the total sediment flux $\left(Q_{\text {total }}\right)$ is defined as the sum of sediment discharged upstream into the floodplain as measured, for example, from sediment gauging $\left(Q_{\mathrm{up}}\right)$, and the flux eroded from bank retreat $\left(Q_{\text {be }}\right)$. The mixed sediment flux, comprising a mixed nuclide concentration $C_{\text {mix }}$, is now transferred into the next compartment where it is incorporated again into the floodplain for the same duration $\Delta t$. Because all parameters are held constant for all compartments and $l_{\text {compartment }}$ is derived from $l_{\text {river }}$ divided by $N$, the calculated mass fluxes are independent from the actual number of compartments. Thus, the accumulation or decay of cosmogenic nuclides can be monitored as sediment moves downstream from one floodplain compartment to the next, and the relative change in nuclide concentration can be predicted. 
The design of this model is based on certain assumptions: (i) During bank erosion, all floodplain sediment, regardless of grain size, is vertically well mixed. By integrating over the entire depth of the bank, average nuclide concentrations can be calculated. (ii) All sediment particles, regardless of grain size, are uniformly distributed throughout the floodplain in all directions. In natural settings, floodplain deposits are usually capped by a clay layer formed by overbank deposition. Such layers do not necessarily contain the grain size analyzed for cosmogenic nuclides, thus the budget will be dominated by deeper, better shielded coarsegrained floodplain deposits. (iii) During lateral erosion and deposition, all particles are reworked by the river, including bedload, transitional and suspended load. (iv) Bypassing of sediment without incorporation and intermediate storage is quantified by the ratio of the incoming sediment flux ( $\left.Q_{\text {up }}\right)$ and the bank erosion flux $\left(Q_{\text {bank }}\right)$. (v) The volume of sediment reworked in the floodplain stays constant as the floodplain does not aggrade nor does it incise. This assumption is justified for quasisteady state settings. (vi) Over the time of one liberation cycle, all floodplain material is reworked uniformly at a constant rate by the migrating river. The model does not include gradients in the reworking recurrence with increasing distance from the active channel.

Our approach differs considerably from the way Yanites et al. (2009) assess the effect of storage of land slide-derived material in a river basin. In their model, Yanites et al. (2009) consider the effects of sediment storage on cosmogenic ${ }^{10} \mathrm{Be}$ nuclide concentrations in erosional settings, where landslide material is usually prone to storage before it is removed by rivers and in the process is mixed with material from source area erosion processes. In contrast to the Yanites et al. study, which addresses storage effects near the sediment source in very small catchments, the focus of our analysis is on sediment reworking by lateral channel migration. Our model incorporates these processes and has been designed to describe multi compartment-based, depositional systems in which the sediment, albeit being stored over timescales of $10^{3} \mathrm{y}$, is also continuously being reworked by the river in large fluvial systems.

\section{Choice of model parameters for representative river settings}

We have chosen to model six characteristic river settings that encompass the entire range of shallow and deep channels, wide and narrow channel belt widths, and fast and slow channel migration rates (Table 1). For both the Amazon River at Manacapuru and the Beni River basin near Riberalta, Dosseto et al. (2006a,b) have measured sediment residence times 
of $4 \mathrm{ky}$ using U-series. It has to be pointed out that Dosseto's sediment residence time estimated for the Beni floodplain excludes storage in the Bolivian Andes; the storage period within the Bolivian Andes has been characterized separately with U-series (Dosseto et al., 2006b). For the Madeira River basin (including the Beni floodplain) at the Amazon confluence, a floodplain sediment residence time of 14 ky has been measured by Dosseto et al. (2006b). We use this value for the Amazon floodplain instead (see Table 1). For the Rhine River, a cumulative sediment residence time of $\sim 9 \mathrm{ky}$ is based on careful sediment budgets (Hoffmann et al., 2007). A maximum sediment age constraint (16 ky) from stratigraphic sections is available for the Mississippi River (Knox, 2006), which we have also taken as an approximation for Mississippian tributaries (the Vermillion and Pearl Rivers), in the absence of measured rates. A measured upstream nuclide concentration, $C_{\text {up }}$ was used where available. For the cases of the Mississippi, Pearl, and Vermillion Rivers, where nuclide concentrations have not yet been measured, concentrations were calculated using Lal's (1991) formalism for spatially averaged erosion. To this end, the hinterland denudation rate $\varepsilon$ of each basin was estimated by dividing a given rivers' total sediment flux $Q_{u p}$ at the respective gauging station by the upstream (hinterland) sediment-producing area and converting the resulting sediment yield $\left(\mathrm{t} / \mathrm{km}^{2} / \mathrm{y}\right)$ into a denudation rate by dividing it by the eroding bedrock density (in this case $\left.2.7 \mathrm{~g} / \mathrm{cm}^{3}\right)$ :

$$
C_{u p}=\frac{P_{(0)}}{\lambda+\frac{\varepsilon}{Z^{*}}}
$$

The mean basin surface production rate $P_{(0)}$ was calculated using the mean basin elevation and production rate scaling was done following Dunai (2000) (see Table 1). $z^{*}$ gives the cosmic ray absorption depth scale, typically $600 \mathrm{~mm}$ in silicate rocks, over which this method integrates. In the case of calculating $C_{\text {up }}$, we simplified Eq. 8 and ignored the small contribution to the production of nuclides by muons. The channel migration rates were usually estimated from meander bend migration, which might lead to an overestimation of the migration rate; also, the process might be unsteady because of involvement of avulsions. These effects lead to a longer sediment residence time and will be evaluated further down in this text. 


\section{Dynamic steady state floodplain model results}

As expected for dynamic, active floodplains where sediment is stored for thousands of years, both ${ }^{10} \mathrm{Be}$ and ${ }^{26} \mathrm{Al}$ do not strongly decay but in some cases show an increase in nuclide concentration. The maximum increase in nuclide concentration (in percent) for each river is given in Table 1 and shown in Fig. 2. The increase in ${ }^{10}$ Be nuclide concentration for all rivers is between 0.6 and $10.7 \%$ relative to the starting ${ }^{10} \mathrm{Be}$ nuclide concentration $C_{\text {up }}$ inherited from the sediment source area during erosion. The relative increase in ${ }^{26} \mathrm{Al}$ concentration is virtually identical because the production mechanisms are similar to those of ${ }^{10} \mathrm{Be}$ and storage periods are too short to allow for detectable radioactive decay. Some differences in accumulation between rivers are predicted, however.

In the Pearl River case, the increase is $\sim 11 \%$, which is the largest increase of all modeled settings. This increase of the mixed nuclide concentration is primarily controlled by the ratio of ingoing sediment flux $\left(Q_{\text {up }}\right)$ to total flux eroded from the banks $\left(Q_{\text {be }}\right)$, which is calculated from Eq. 4. In general, if the bank erosion flux is higher than the sediment input from upstream, nuclides produced from exposure in the floodplain surface and upper subsurface will dominate the sediments' nuclide budget, resulting in net nuclide accumulation if storage times are long and floodplain reworking depths are shallow. For the Pearl River, this ratio is 4.4 (see Table 1), which is the same as in the Beni River case, although here, the increase in nuclide concentration is only $<1 \%$. For both rivers having the same $Q_{\text {up }} / Q_{\text {be }}$ ratio, the controlling factor lies in this case in the residence time, which is four times higher for the Pearl River, accounting for a stronger nuclide increase. By comparing, e.g., the Amazon and the Rhine Rivers (both having similar $Q_{\mathrm{up}} / Q_{\text {be }}$ ratios of 1.7 and 1.6, respectively), it becomes evident that the individual ratios cannot be directly compared with each other because of the differences in factors contributing to $Q_{\text {be }}$ (see Eq. 4), such as different channel depths and different residence times. The Vermillion River has the highest ratio $\left(Q_{\text {up }} / Q_{\text {be }}=150\right)$ of all investigated settings, thus sediment is routed rapidly through the floodplain and no change in nuclide concentration would be expected. However, the small increase modeled can be explained by the rivers' shallow depth, resulting in high surface nuclide accumulation as the nuclides produced are not diluted by deeply buried sediment.

In general, the observed increase in ${ }^{10} \mathrm{Be}$ nuclide concentrations is with $\sim 1-11 \%$ in the typical range of the overall reproducibility of nuclide concentrations in river sediment. This reproducibility is governed by both analytical precision and natural variability in upstream nuclide concentrations. Therefore, this increase is only just detectable for the case of lowest analytical error and highest possible increase. However, even if the detection of a change in 
nuclide concentration in real floodplains can be achieved analytically, the variation of the source area denudation rates in space and time is mostly larger than the predicted model increase.

To explore a threshold at which a hypothetical storage time is so long that an increase in nuclide concentration becomes analytically resolvable, we have calculated a storage detection limit that is arbitrarily defined as an increase (or decrease) of $20 \%$ in mixed nuclide concentration (see Eq. 7) relative to $C_{\mathrm{up}}$. This time limit is river specific and varies from 0.07 My for the Rhine to 2.2 My for the Amazon River (Table 1). In all cases, the predicted detection limits are much longer than the cumulative residence times of these rivers. On significantly longer timescales still, cosmogenic nuclide concentrations will equilibrate to a uniform steady state nuclide concentration.

As a consequence, we suggest that floodplain storage in all modeled river settings does not result in a change in ${ }^{10} \mathrm{Be}$ or ${ }^{26} \mathrm{Al}$ concentration. For deep rivers like the Beni or the Amazon, this tendency can be attributed to the high proportion of well-shielded sediment, leading to a lack of irradiation within the floodplain. In shallow rivers like the Vermillion River, floodplain sediment is well irradiated, but the mass eroded from the floodplain is small and is swamped by upstream sediment. In all cases, total storage times are too short to allow for radioactive decay of ${ }^{10} \mathrm{Be}$ or ${ }^{26} \mathrm{Al}$ (see Fig. 2).

The result for in situ-produced ${ }^{14} \mathrm{C}$ is different. Because of the short half life decay is much more pronounced, and a significant decrease in ${ }^{14} \mathrm{C}$ between 8 and $48 \%$ is observed for all rivers. Only the Vermillion River shows no decrease because it features rapid sediment routing, evidenced by a high $Q_{\text {up }} / Q_{\text {be }}$ ratio. Similar to what has been observed for ${ }^{10} \mathrm{Be}$ and ${ }^{26} \mathrm{Al}$, the magnitude of the observed decrease in ${ }^{14} \mathrm{C}$ nuclide concentrations for all other settings is not directly related to the sediment residence time, but is a combination of residence time, channel depth, and $Q_{\text {up }} / Q_{\text {be }}$. If ${ }^{14} \mathrm{C}$ concentrations were only a function of sediment residence time, the total decay of the nuclide after 3-4 half lives would be expected, which is clearly not predicted here. Pending on the ability to perform routine measurements of in situ-produced ${ }^{14} \mathrm{C}$, the short half life of this isotope appears to be in the perfect range to quantify storage timescales.

\subsection{The Beni River example}

The Beni River is an upper Amazon tributary; its floodplain is a thoroughly investigated system where modern migration rates, recent sediment discharge, and bank erosion rates are well known (Guyot et al., 1996; Aalto, 2002; Aalto et al., 2003; Gautier et 
al., 2007). ${ }^{10}$ Be concentrations of Beni River floodplain sediment have also been investigated in detail (Wittmann, 2008). Therefore, the sensitivity of the model to changes in boundary conditions is explored more thoroughly, and data from in situ-produced cosmogenic ${ }^{10} \mathrm{Be}$ measurements in floodplain sediment will be evaluated.

For the Beni, the steady state assumption has been validated by Aalto et al. (2002), who have measured the Beni cutbank erosion flux (210 Mt/y) as well as fluxes from point bar redeposition (200 Mt/y). Both are identical to the total annual flux passed on from the sediment-producing areas, the Andes, to the floodplain (210 Mt/y; Table 1). "Standard” model runs were calculated using parameters representative of the natural Beni system (see Table 1). The model prediction is that the increase in ${ }^{10} \mathrm{Be}$ concentration at the floodplain outlet is only 230 at $/ \mathrm{g}_{(\mathrm{Qz})}$, corresponding to an increase of $0.6 \%$ (Fig. 3A). Changes to these boundary conditions result in the following conclusions: the system is very sensitive to the magnitude of sediment discharged from the sediment-producing hinterland. If this flux, for example, is decreased by four orders of magnitude from 200 to $0.02 \mathrm{Mt} / \mathrm{y}$ whilst keeping the nuclide concentration $C_{\text {up }}$ constant, the nuclide signal produced within and eroded from the river banks will increase by ca. $1200 \mathrm{at} / \mathrm{g}_{(\mathrm{Qz})}$, corresponding to $3.1 \%$ of the initial nuclide budget. If the ingoing nuclide concentration is decreased significantly from its starting concentration of $3.8 \times 10^{4}$ at $/ \mathrm{g}_{(\mathrm{Qz})}$ to $0.5 \times 10^{4}$ at $/ \mathrm{g}_{(\mathrm{Qz})}$, as would be expected from very high erosion rates, the nuclide change will amount to an increase of $4.7 \%$ relative to the starting nuclide concentration. A fifteenfold increase in sediment storage time, as might be expected from changes in climatic or tectonic conditions, causes ${ }^{10}$ Be nuclides to accumulate by only $5.8 \%$ over Beni River floodplain distances. A fourfold decrease in channel depth, from 20 to 5 m, would not result in a significant nuclide concentration change because most nuclides are produced within the uppermost meters of sediment. This is also the reason why the admixture of sediment remobilized during large but locally-limited avulsions would not matter much: floodplain storage is usually so deep that only the uppermost meters are being irradiated. We conclude that the ${ }^{10} \mathrm{Be}$ nuclide concentration of the Beni River is likely to be preserved throughout transfer of sediment through the floodplain.

Along $500 \mathrm{~km}$ of Beni River floodplain, 13 cosmogenic nuclide measurements have been obtained from river sediment by Wittmann (2008), including one replicate and three grain size duplicate samples (see Fig. 3B). Along this floodplain distance, no significant variation in ${ }^{10} \mathrm{Be}$ nuclide concentration has been observed. Wittmann (2008) found that the ${ }^{10} \mathrm{Be}$ nuclide signal is invariant over floodplain distances of $>500 \mathrm{~km}$ from the Andean foothills to the Madeira confluence, despite the channel having shifted across the foreland 
basin from the SE to the current position over Holocene timescales (Dumont, 1996). A fluxand area-weighted nuclide concentration of $3.9 \pm 0.6 \times 10^{4}$ at $/ \mathrm{g}_{(\mathrm{Qz})}$ was measured (see Fig. 3B). This preliminary result strongly supports our modeling efforts, which predicts the absence of concentration changes at residence times measured with $U$-series by Dosseto et al. (2006a,b). This finding allows for the implication that the denudation rate signal of the sedimentcontributing areas, in this case the Bolivian Andes, is preserved over these floodplain distances.

\section{The change of cosmogenic nuclide composition during long-term storage}

Burial dating techniques using cosmogenic isotope pairs, e.g. ${ }^{10} \mathrm{Be}$ and ${ }^{26} \mathrm{Al}$, can provide the storage duration if the sediment has been buried rapidly and deeply, so that ideally, all nuclide production ceases and the nuclide concentration inherited from the source prior to deposition is only modified by radioactive decay (Granger and Muzikar, 2001). For example, rates of landscape change can be quantified from dating the burial time of cave sediments (e.g. Granger et al. 1997; Granger et al. 2001). The method can be applied to a variety of other settings, e.g. to characterize complicated glacial sequences in order to infer ice advances (e.g. Balco et al., 2005) or to establish the temporal and spatial variability in glacial erosion (e.g. Willenbring-Staiger et al., 2006), but can also be used to derive basinwide paleoerosion histories preserved in terrace or alluvial records (Schaller et al., 2002; Schaller et al., 2004; Balco and Stone, 2005) if an independent deposit age estimate is available.

We will show in the following that these burial dating techniques can be adapted to settings where no independent age estimate is available, albeit the derived burial ages and depths are minimum estimates and do not yield precise storage duration. Similar to burial dating of terrace sequences, but very different to the dynamic steady state floodplain settings explored above, we assume that the floodplain sediment is stored over the long term $\left(>10^{6} \mathrm{y}\right)$ without incorporation into the active fluvial system and the sediment is not mixed by fluvial processes. To explore such a static system where no exchanges of nuclide or sediment fluxes occur, ${ }^{10} \mathrm{Be}$ nuclide concentrations were first of all plotted versus storage time (see Fig. 4A). The evolution of the ${ }^{10} \mathrm{Be}$ signal, as calculated for a starting nuclide concentration of 50,000 $\mathrm{at} / \mathrm{g}_{(\mathrm{Qz})}$, indicates that burial depth has a large effect on ${ }^{10} \mathrm{Be}$ concentrations for storage durations exceeding 0.5 My. At the surface of the deposits, nuclides continue to accumulate, whilst at depth, nuclide concentrations are mostly a function of burial depth (Schaller et al., 2004). When plotting the ${ }^{26} \mathrm{Al} /{ }^{10} \mathrm{Be}$ ratio (Fig. 4B) for the same conditions, it becomes clear that burial age has the largest effect on the ${ }^{26} \mathrm{Al} /{ }^{10} \mathrm{Be}$ ratio which does not depend so strongly on depth as the ${ }^{10} \mathrm{Be}$ nuclide concentration alone. The concentration effect occurs because 
while nucleons continuously irradiate the surface, muons also penetrate deeply into the subsurface, causing post-depositional irradiation, and both production types are depthdependent. This effect counterbalances decay until eventually secular equilibrium between irradiation and decay is achieved (Granger and Muzikar, 2001). However, the depthdependency becomes less pronounced with increasing nuclide inheritance while the agedependence increases, because more nuclides decay relative to new production (Fig. 4B).

Given that the ${ }^{10} \mathrm{Be}$ concentration is mostly a function of depth, whereas the ${ }^{26} \mathrm{Al} /{ }^{10} \mathrm{Be}$ ratio records the burial age, both unkowns can be derived in a combined ratio vs concentration diagram. Figure 4C shows such a modified erosion island plot (Lal, 1991), which results from a combination of Figs. 4A and B. In this version of the plot, we have contoured the area below the constant surface exposure line with isodepth curves that correspond to sediment burial depths, and also for curves of equal burial duration (assuming continuous irradiation during burial from nucleons and muons). Both burial depth and duration are minimum estimates due to possible multiple burial episodes.

\subsection{The Amazon floodplain example}

Figure 4C is used to interpret cosmogenic nuclide data from a main Amazon River floodplain. In the Varzea do Curuaí located in the central Amazon basin (see Fig. 5), the local processes involving water and sediment transport have now been studied for several years (Maurice-Bourgoin et al., 2007; Bonnet et al., 2008). Geologically, the northern and eastern parts of the floodplain are composed of modern floodplain sediments (e.g., Quaternary age, mostly fine grained sand to mud). Samples Soc and Gran represent active floodplain sediment samples. The southern part is comprised of Cretaceous to Miocene floodplain deposits that are connected to the active floodplain by the ground water table, consisting of fine- to coarsegrained sands (Rossetti et al., 2005; Rossetti and Valeriano, 2007). Lago Curumucuri (sample Curu, taken from the lake bottom) is located at the transition between modern and Miocene floodplain, where the Miocene floodplain has been preserved from inundation because of its slightly increased elevation.

The modern floodplain samples (Soc and Gran) average to a ${ }^{10} \mathrm{Be}$ nuclide concentration of $5.2 \pm 0.4 \times 10^{4}$ at $/ \mathrm{g}_{(\mathrm{Qz})}(n=5)$, and an average ${ }^{26} \mathrm{Al} /{ }^{10} \mathrm{Be}$ ratio of $6.3 \pm 1.3(n=$ 4), plotting on or close to the surface exposure curve and thus not displaying sediment burial. Miocene floodplain samples (Curu) display significantly higher ${ }^{10} \mathrm{Be}$ concentrations of $12.5 \pm$ $0.6 \times 10^{4}$ at $/ \mathrm{g}_{(\mathrm{Qz})}(n=2)$ and an average ${ }^{26} \mathrm{Al} /{ }^{10} \mathrm{Be}$ ratio of $3.1 \pm 0.6(n=2)$, thus showing significant burial. Assuming continuous irradiation during burial, these ratios would result in a 
burial duration of $\sim 4$ to $>5 \mathrm{My}$ at burial depths of 7-12 m (see Fig. 4C). Assuming complete burial without additional irradiation, minimum burial ages of 1-2 My can be calculated for these samples. This result is compatible with the age of Miocene floodplain sediments surrounding Lago Curumucuri.

In case that these old floodplain deposits are reworked and admixed into the modern Amazon river system via channel rerouting, modification of the otherwise source-area dominated nuclide signal is predicted if the volume of the eroded deposit material significantly alters the $Q_{\text {up }} / Q_{\text {be }}$ ratio. Using our modified erosion island plot however, it is possible to clearly distinguish between deposits that have not been tapped by the modern river, showing very low ${ }^{26} \mathrm{Al} /{ }^{10} \mathrm{Be}$ ratios and burial ages of $>5 \mathrm{My}$, and the dynamic system of the modern Amazon River and its floodplain.

\section{Summary}

For all tested settings encompassing a wide range of dynamic fluvial settings from confined, shallow rivers with small floodplains to foreland-basin scale, actively migrating rivers, our model results suggest that the signal of long-lived nuclides such as ${ }^{26} \mathrm{Al}$ and ${ }^{10} \mathrm{Be}$ is inherited from the eroding source area. Even long residence times or the removal of deeply stored sediment via river migration and avulsion do not induce a significant change in the mixed nuclide signal, because in sediment-laden rivers, the upstream flux is overwhelming the signal contributed by bank erosion. In sediment-starved rivers, usually deep floodplain erosion results in the incorporation of sediment that has been shielded from irradiation. In shallow rivers, the bank erosion flux is too small to change the concentration of the mixed signal in the stream. In all cases, the source signal is likely to be preserved.

The consequence for ${ }^{10} \mathrm{Be}$ and ${ }^{26} \mathrm{Al}$ transfer through dynamic, active floodplains that are constantly being reworked by their traversing rivers is that a denudation rate of the hinterland can, in all cases, be determined. Floodplain storage evidently does not modify nuclide concentrations introduced from the sediment source area to the floodplain. Thus the production rate used for calculation of basin-averaged denudation rates has to be limited to the sediment-producing area, rather than basing the production rate calculation on the entire catchment area. We define this denudation rate as "floodplain-corrected".

If times of residence, storage, and transfer shall be determined, then in situ-produced ${ }^{14} \mathrm{C}$ is the method of choice. Given that irradiation is almost absent, the radioactive decay of 
this shorter-lived nuclide potentially provides the sought residence times. Analytical methods are not yet routine but are expected to be so soon (Lifton et al., 2001; Pigati et al., 2007).

Similarly, for tapping sediment after prolonged storage $\left(10^{5}-10^{6} \mathrm{y}\right)$, the differential decay of ${ }^{10} \mathrm{Be}$ versus ${ }^{26} \mathrm{Al}$ has the potential to provide storage durations and storage depths. The example of ${ }^{26} \mathrm{Al}$ and ${ }^{10} \mathrm{Be}$ nuclide concentrations measured in floodplain lakes located in Holocene and Miocene sediment, respectively, both present within the central Amazon River system, shows that these old floodplain lakes have not been tapped by the modern river, as they show very low ${ }^{26} \mathrm{Al} /{ }^{10} \mathrm{Be}$ ratios and burial ages of $>5 \mathrm{My}$. These settings are in all cases distinct from the modern floodplain.

Most promising is the application of these long-lived cosmogenic nuclides to sedimentary records, where paleodenudation rates can be determined from the inheritance, and deposition ages from ${ }^{26} \mathrm{Al} /{ }^{10} \mathrm{Be}$ ratios (Schaller et al., 2004).

\section{Acknowledgements}

The authors want to sincerely thank Jane K. Willenbring for her thoughtful and thorough comments on this manuscript. We are grateful to Thomas Hoffmann for sharing his Rhine River data and expertise and also want to thank Marcus Oelze for assistance with model calculations and Kevin P. Norton for discussions. We would also like to thank Anthony Dosseto for reviewing this manuscript. The cosmogenic data from the Beni River and the Varzea do Curuaí have been obtained with the help from Jean-Loup Guyot, Laurence Maurice, and Peter W. Kubik during the first authors Ph.D. study. This work was supported by DFG grant $\mathrm{Bl}$ 562/2-2.

\section{References}

Aalto, R., 2002. Geomorphic form and process of sediment flux within an active orogen: denudation of the Bolivian Andes and sediment conveyance across the Beni foreland. Ph.D. Thesis, University of Washington, Washington, USA.

Aalto, R., Dunne, T., Nittrouer, C., Maurice-Bourgoin, L., Montgomery, D., 2002. Fluvial transport of sediment across a pristine tropical foreland basin: channel-flood plain interaction and episodic flood plain deposition. Alice Springs Symposium Proceedings, Alice Springs, Australia. In: The Structure, Function and Management Implications of Fluvial Sedimentary Systems. IAHS Publications 276, pp. 339-344.

Aalto, R., Maurice-Bourgoin, L., Dunne, T., Montgomery, D., Nittrouer, C., Guyot, J., 2003. Episodic sediment accumulation on Amazonian flood plains influenced by El Nino/Southern Oscillation. Nature 425, 493-497.

Asselman, N., 1999. Suspended sediment dynamics in a large drainage basin: the River Rhine. Hydrological Processes 13, 1437-1450. 
Balco, G., Stone, J.O.H., 2005. Measuring middle Pleistocene erosion rates with cosmic-rayproduced nuclides in buried alluvial sediment, Fisher Valley, southeastern Utah. Earth Surface Processes and Landforms 30, 1051-1067.

Balco, G., Stone, J.O.H., Jennings, C., 2005. Dating Plio-Pleistocene glacial sediments using the cosmic-ray-produced radionuclides ${ }^{10} \mathrm{Be}$ and ${ }^{26} \mathrm{Al}$. American Journal of Science 305, $1-41$.

Bierman, P., Steig, E., 1996. Estimating rates of denudation using cosmogenic isotope abundances in sediment. Earth Surface Processes and Landforms 21, 125-139.

Bonnet, M., Barroux, G., Martinez, J., Seyler, F., Moreira-Turcq, P., Cochonneau, G., Melack, J., Boaventura, G., Maurice-Bourgoin, L., Leon, J., Roux, E., Calmant, S., Kosuth, P., Guyot, J.-L., Seyler, P., 2008. Floodplain hydrology in an Amazon floodplain lake (Lago Grande de Curuai). Journal of Hydrology 349, 18-30.

Bridge, J., 2003. Rivers and Floodplains-Forms, Processes, and Sedimentary Record. Blackwell Science Ltd (Ed.), Blackwell Publishing, Oxford, UK.

Chmeleff, J., von Blanckenburg, F., Kossert, K., Jakob, D., 2009. Determination of the ${ }^{10} \mathrm{Be}$ half life by multi collector ICP-mass spectrometry and liquid scintillation counting. Goldschmidt Conference Abstract, Geochimica et Cosmochimica Acta 73.

Dosseto, A., Bourdon, B., Gaillardet, J., Allégre, C., Filizola, N., 2006a. Time scale and conditions of weathering under tropical climate: Study of the Amazon basin with Useries. Geochimica et Cosmochimica Acta 70, 71-89.

Dosseto, A., Bourdon, B., Gaillardet, J., Maurice-Bourgoin, L., Allégre, C., 2006b. Weathering and transport of sediments in the Bolivian Andes: time constraints from uranium-series isotopes. Earth and Planetary Science Letters 248, 759-771.

Dumont, J., 1996. Neotectonics of the Subandes-Brazilian craton boundary using geomorphological data: the Marañón and Beni basins. Tectonophysics 259, 137-151.

Dunai, T., 2000. Scaling factors for production rates of in situ produced cosmogenic nuclides: a critical reevaluation. Earth and Planetary Science Letters 176, 157-169.

Dunne, T., Mertes, L., Meade, R., Richey, J., Forsberg, B., 1998. Exchanges of sediment between the flood plain and channel of the Amazon River in Brazil. Bulletin of the Geological Society of America 110, 450-467.

Gautier, E., Brunstein, D., Vauchel, P., Roulet, M., Fuertes, O., Guyot, J., Darozzes, J., Bourrel, L., 2007. Temporal relations between meander deformation, water discharge and sediment fluxes in the floodplain of the Rio Beni (Bolivian Amazonia). Earth Surface Processes and Landforms 32, 230-248.

Granger, D.E., Kirchner, J.W., Finkel, R.C., 1997. Quaternary downcutting rate of the New River, Virginia, measured from differential decay of cosmogenic ${ }^{26} \mathrm{Al}$ and ${ }^{10} \mathrm{Be}$ in cavedeposited alluvium. Geology 25, 107-110.

Granger, D.E., Muzikar, P.F., 2001. Dating sediment burial with in situ-produced cosmogenic nuclides: theory, techniques, and limitations. Earth and Planetary Science Letters 188, 269-281.

Granger, D.E., Fabel, D., Palmer, A.N., 2001. Pliocene-Pleistocene incision of the Green River, Kentucky, determined from radioactive decay of cosmogenic ${ }^{26} \mathrm{Al}$ and ${ }^{10} \mathrm{Be}$ in Mammoth Cave sediments. Bulletin of the Geological Society of America 113, 825-836.

Guyot, J.L., Filizola, N., Quintanilla, J., Cortez, J., 1996. Dissolved solids and suspended sediment yields in the Rio Madeira basin, from the Bolivian Andes to the Amazon. Exeter Symposium Proceedings, Exeter, UK. In: Erosion and Sediment Yield: Global and Regional Perspectives. IAHS Publications 236, pp. 55-63.

Heisinger, B., Lal, D., Jull, A.J.T., Kubik, P.W., Ivy-Ochs, S., Knie, K., Nolte, E., 2002. Production of selected cosmogenic radionuclides by muons: 2. Capture of negative muons. Earth and Planetary Science Letters 200, 357-369.

Hoffmann, T., Erkens, G., Cohen, K.M., Houben, P., Seidel, J., Dikau, R., 2007. Holocene floodplain sediment storage and hillslope erosion within the Rhine catchment. The Holocene 17, 105-118. 
Hudson, P., Kesel, R., 2000. Channel migration and meander-bend curvature in the lower Mississippi River prior to human modification. Geology 28, 531-534.

Jerolmack, D.J., Mohrig, D., 2007. Conditions for branching in depositional rivers. Geology 35, 463-466.

Kesel, R., 1988. The decline in the suspended load of the Lower Mississippi River and its influence on adjacent Wetlands. Environmental Geology and Water Sciences 11, 271281.

Kesel, R., Yodis, E., McCraw, D., 1992. An approximation of the sediment budget of the lower Mississippi river prior to major human modification. Earth Surface Processes and Landforms 17, 711-722.

Knox, J., 2006. Floodplain sedimentation in the Upper Mississippi Valley: Natural versus human accelerated. Geomorphology 79, 286-310.

Korschinek, G., Bergmaier, A., Dillmann, I., Faestermann, Th., Gerstmann, U., Knie, K., Lierse von Gostomski, Ch., Maiti, M., Poutivtsev, M., Remmert, A., Rugel, G., Wallner, A., 2009. Determination of the ${ }^{10} \mathrm{Be}$ half life by HI-ERD and liquid scintillation counting. Goldschmidt Conference Abstract, Geochimica et Cosmochimica Acta 73.

Kubik, P.W., Ivy-Ochs, S., Masarik, J., Frank, M., Schluechter, C., $1998 .{ }^{10} \mathrm{Be}$ and ${ }^{26} \mathrm{Al}$ production rates deduced from an instantaneous event within the dendro-calibration curve, the landslide of Koefels, Oetz Valley, Austria. Earth and Planetary Science Letters 161, 231-241.

Lal, D., 1991. Cosmic ray labeling of erosion surfaces: in situ nuclide production rates and erosion models. Earth and Planetary Science Letters 104, 424-439.

Lauer, J., Parker, G., 2008. Net local removal of floodplain sediment by river meander migration. Geomorphology 96, 123-149.

Libby, W., 1955. Radiocarbon Dating. University of Chicago (Ed.), University of Chicago Press, Chicago.

Lifton, N.A., Jull, A.J.T., Quade, J., 2001. A new extraction technique and production rate estimate for in situ cosmogenic ${ }^{14} \mathrm{C}$ in quartz. Geochimica et Cosmochimica Acta 65, 1953-1969.

Magilligan, F., 1985. Historical floodplain sedimentation in the Galena River Basin, Wisconsin and Illinois. Annals of the Association of American Geographers 75, 583594.

Maurice-Bourgoin, L., Bonnet, M., Martinez, J., Kosuth, P., Cochonneau, G., Moreira-Turcq, P., Guyot, J., Vauchel, P., Filizola, N., Seyler, P., 2007. Temporal dynamics of water and sediment exchanges between the Curuaí floodplain and the Amazon River, Brazil. Journal of Hydrology 335, 140-156.

Meade, R., 2007. Transcontinental Moving and Storage: the Orinoco and Amazon rivers transfer the Andes to the Atlantic. In: Gupta, A. (Ed.), Large Rivers: Geomorphology and Management. John Wiley \& Sons Ltd, Chichester, UK, pp. 45-63.

Mertes, L., Dunne, T., Martinelli, L., 1996. Channel-floodplain geomorphology along the Solimoes-Amazon River, Brazil. Bulletin of the Geological Society of America 108, 1089-1107.

Milliman, J., Syvitski, J., 1992. Geomorphic/tectonic control of sediment discharge to the ocean: the importance of small mountainous rivers. Journal of Geology 100, 525-544.

Pigati, J., Quade, J., Wilson, J., Jull, A., Lifton, N., 2007. Development of low-background vacuum extraction and graphitization systems for ${ }^{14} \mathrm{C}$ dating of old (40-60 ka) samples. Quaternary International 166, 4-14.

Rossetti, D., Valeriano, M., 2007. Evolution of the lowest Amazon basin modeled from the integration of geological and SRTM topographic data. Catena 70, 253-265.

Rossetti, D., Mann de Toledo, P., Góes, A., 2005. New geological framework for Western Amazonia (Brazil) and implications for biogeography and evolution. Quaternary Research 63, 78-89. 
Samworth, E., Warburton, E., Engelbertink, G., 1972. Beta decay of the ${ }^{26} \mathrm{Al}$ ground state. Physical Review C 5, 138-142.

Schaller, M., von Blanckenburg, F., Hovius, N., Kubik, P., 2001. Large-scale erosion rates from in situ-produced cosmogenic nuclides in European river sediments. Earth and Planetary Science Letters 188, 441-458.

Schaller, M., von Blanckenburg, F., Veldkamp, A., Tebbens, L., Hovius, N., Kubik, P.W., 2002. A $30000 \mathrm{yr}$ record of erosion rates from cosmogenic ${ }^{10} \mathrm{Be}$ in Middle European river terraces. Earth and Planetary Science Letters 204, 307-320.

Schaller, M., von Blanckenburg, F., Hovius, N., Veldkamp, A., van den Berg, M., Kubik, P., 2004. Paleoerosion rates from cosmogenic ${ }^{10} \mathrm{Be}$ in a 1.3 Ma terrace sequence: Response of the river Meuse to changes in climate and rock uplift. Journal of Geology 112, 127 144.

Slingerland, R., Smith, N., 2004. River avulsions and their deposits. Annual Review of Earth and Planetary Sciences 32, 257-285.

Soar, P., Thorne, C., Harmar, O., 2005. Hydraulic geometry analysis of the lower Mississippi. Final Report, U.S. Army European Research Office, London.

Trimble, S., 1995. Catchment sediment budgets and change. In: Gurnell, A., Petts, G. (Eds.), Changing River Channels. John Wiley \& Sons, Chichester, UK, pp. 201-215.

von Blanckenburg, F., 2005. The control mechanisms of erosion and weathering at basin scale from cosmogenic nuclides in river sediment. Earth and Planetary Science LettersFrontiers 237, 462-479.

Whipple, K., Tucker, G., 1999. Dynamics of the stream-power river incision model: implications for height limits of mountain ranges, landscape response timescales, and research needs. Journal of Geophysical Research- Solid Earth 104, 17661-17674.

Willenbring-Staiger J.K., Gosse, J.C., Little, E.C., Utting, D.J., Finkel, R., Johnson, J.V., Fastook, J., 2006. Glacial erosion and sediment dispersion from detrital cosmogenic nuclide analyses of till. Quaternary Geochronology 1, 29-42.

Wittmann, H., 2008. New applications to in situ-produced cosmogenic nuclides in river sediment: high mountain belt denudation in the Swiss Alps and Bolivian Andes and sediment transfer and storage in the Amazon basin. Ph.D. Thesis, University of Hannover, Germany.

Wolman, M., Leopold, L., 1957. River Flood Plains: Some Observations on their Formation. Geological Survey Professional Paper 282-C, U.S. Government Printing Office, Washington.

Yanites, B. J., Tucker, G.E., Anderson, R.S., 2009. Numerical and analytical models of cosmogenic radionuclide dynamics in landslide-dominated drainage basins. Journal of Geophysical Research- Earth Surface 114, doi:10.1029/2008JF001088. 


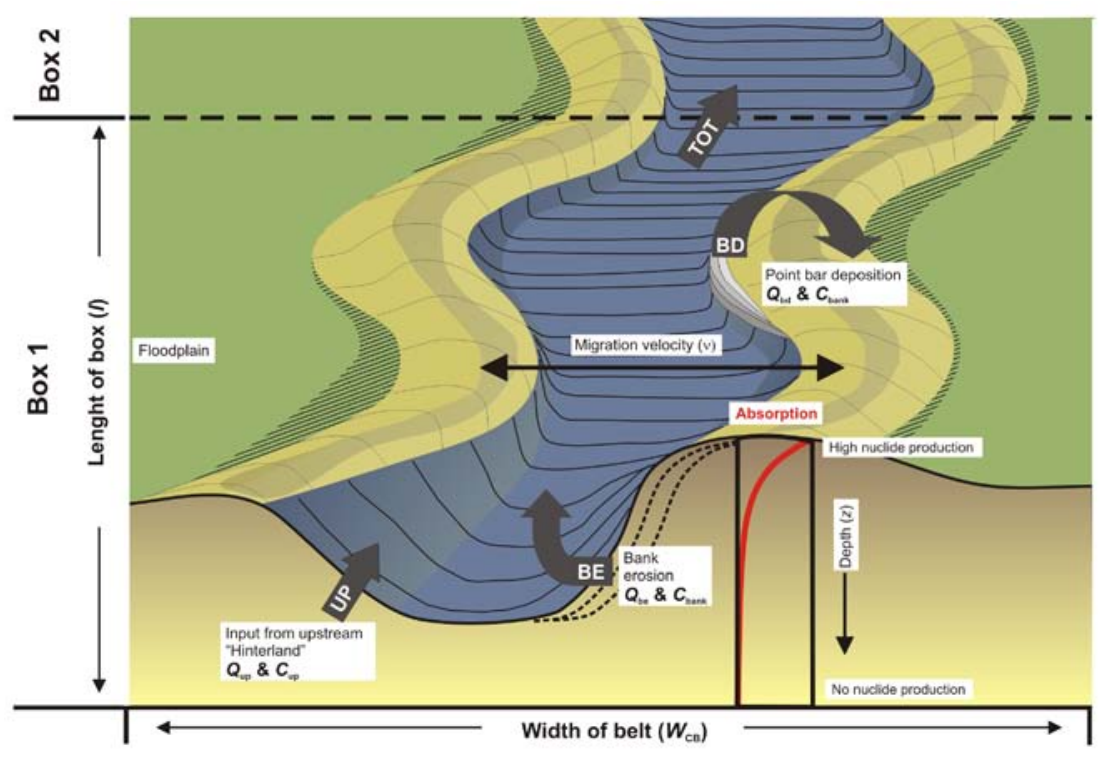

Fig. 1. Cartoon of the model setup. The two main compartments are shown, which are the sediment input from the hinterland $\left(Q_{\text {up }}\right)$ with its characteristic nuclide concentration $\left(C_{\text {up }}\right)$, and the sediment flux eroded from the bank $\left(Q_{\text {be }}\right)$ with its nuclide concentration $C_{\text {bank }}$. Sediment deposition on the point bar $\left(Q_{\text {bd }}\right)$ is equal to $Q_{\text {be }}$ in flux magnitude and nuclide concentration $C_{\text {bank }}$. $C_{\text {bank }}$ is calculated by averaging over the bank depth (resulting in an average bank nuclide concentration $C_{\text {bank(z) }}$, not shown here), equal to the river channel depth, by applying the depth-dependency of nuclide production from Schaller et al. (2002). Sediment is stored in the floodplain for a duration defined by $\square$, the sediment residence time, before it is eroded. The residence time is defined by the time its takes the river to migrate laterally at a certain rate (the migration rate $v$ ) across the width of its channel belt $\left(W_{\mathrm{cb}}\right)$. 


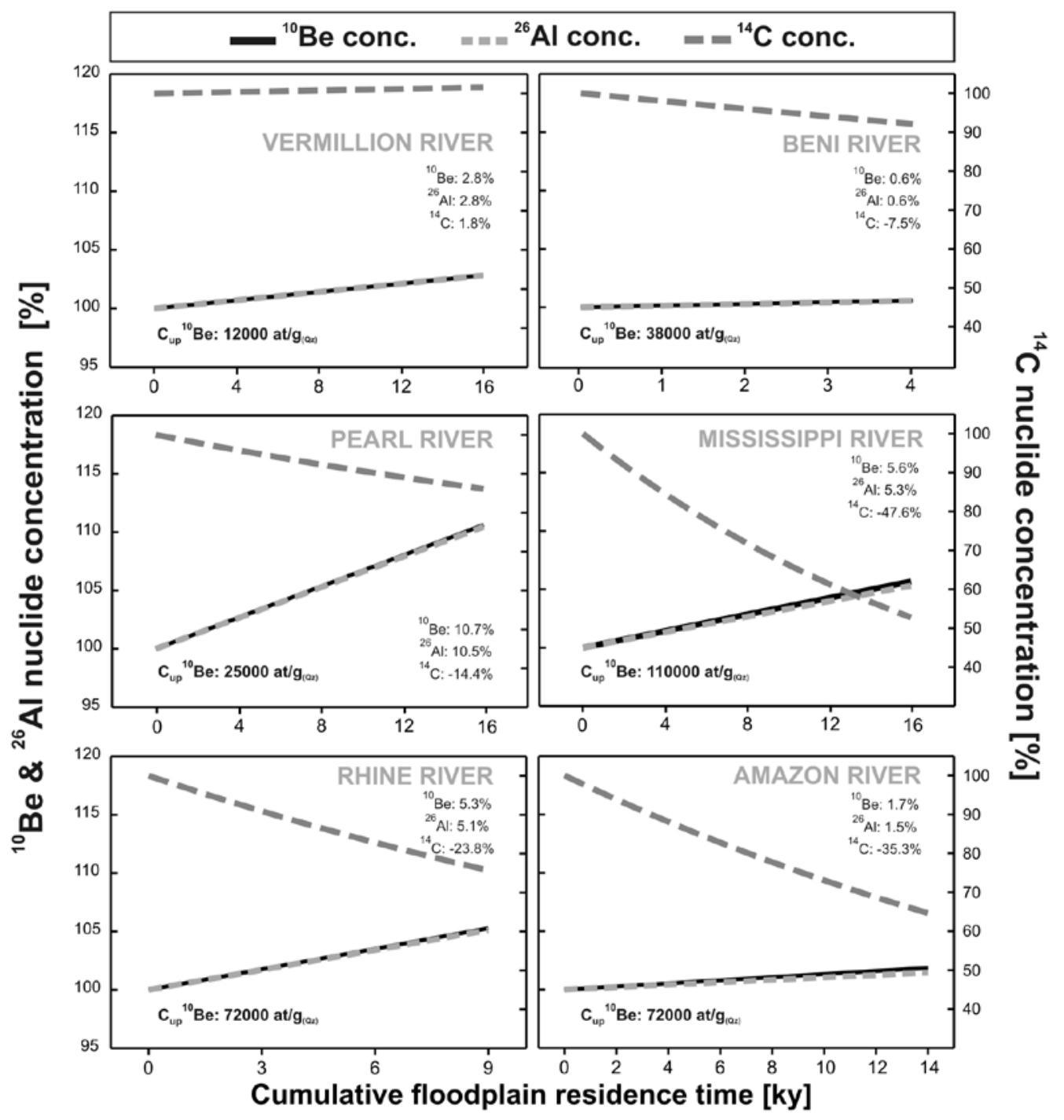

Fig. 2. Model results for each river setting. Plots denote the relative accumulated plus upstream ${ }^{10} \mathrm{Be}$ and ${ }^{26} \mathrm{Al}$ nuclide concentration on the left $Y$-axis, and the ${ }^{14} \mathrm{C}$ concentration on the right $Y$-axis, both normalized to $100 \%$. The $X$-axis gives the cumulative floodplain residence time. ${ }^{14} \mathrm{C}$ nuclide concentrations decay more rapidly, depending on the prevailing residence time for each setting, than ${ }^{26} \mathrm{Al}$ and ${ }^{10} \mathrm{Be}$, which slightly accumulate for each setting, except in the Vermillion River, where sediment routing is very fast. 

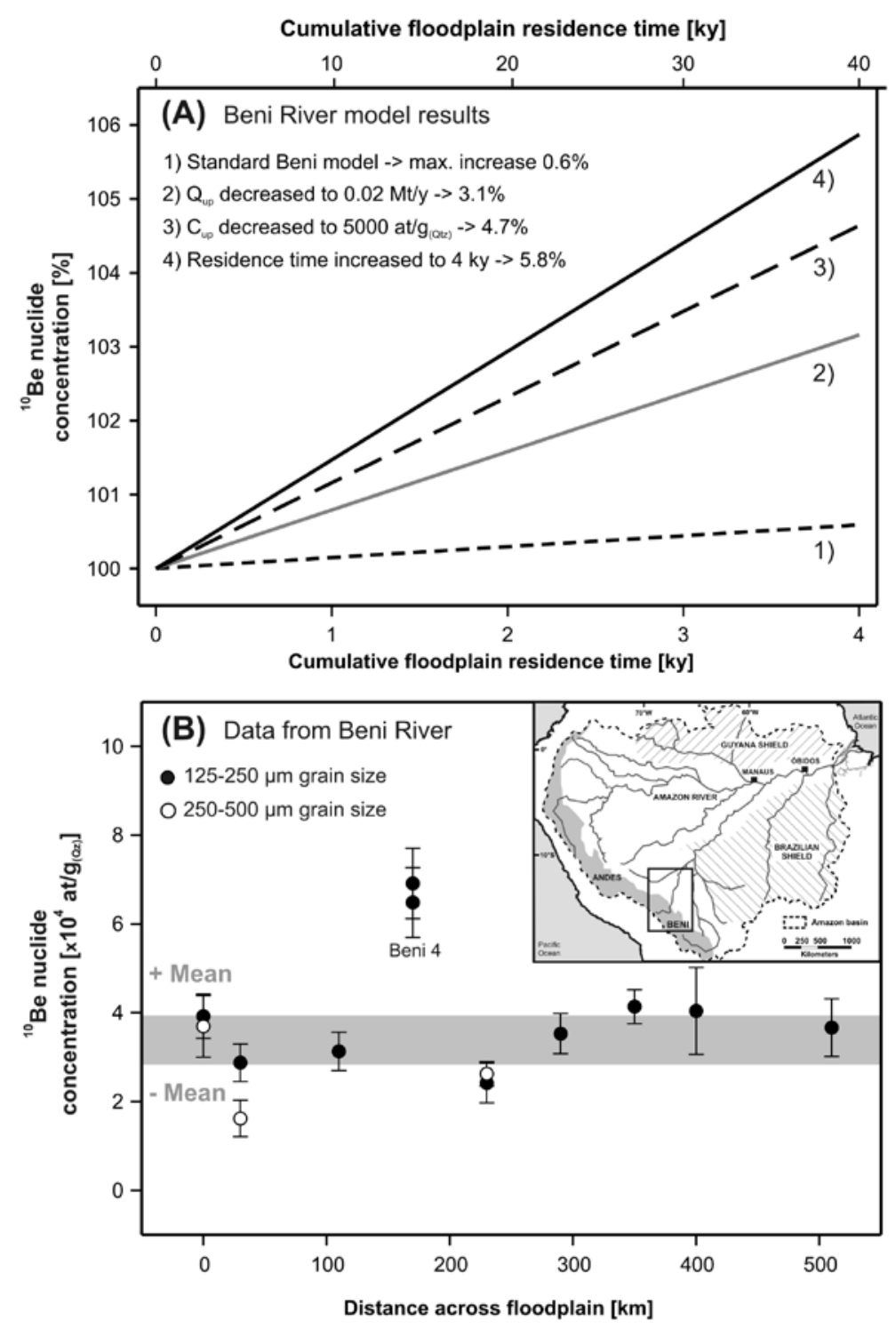

Fig. 3.(A) Model results for the Beni River system. The ${ }^{10} \mathrm{Be}$ concentration ( $Y$-axis) is normalized to an upstream concentration of $100 \%$. $X$-axes give cumulative time sediment is stored in the floodplain. For the standard Beni model (1, black short-dashed line), parameters are taken from Table 1. Other models (2-4) give results for different fluvial boundary conditions in the Beni system as indicated. For all models, the maximum increase (\%) in accumulated nuclide concentration for the last box with respect to the input concentration is given. Not shown for clarity: River depth decreased to $5 \mathrm{~m}$ results in a nuclide increase of $0.6 \%$. (B) Cosmogenic ${ }^{10} \mathrm{Be}$ nuclide data measured from Beni River sediment (Wittmann, 2008) from two grain sizes. For location of river see inset. Outliers are attributed to deviations in grain sizes, and, in the case of sample Beni 4, to possible temporal variations in the initial nuclide concentration within the sediment-producing area (see Wittmann (2008) for details). The grey bar denotes the flux- and area-weighted mean of all samples $(n=13)$, being $3.9 \pm 0.6 \times 10^{4}$ at $/ \mathrm{g}_{(\mathrm{Qz})}$. 

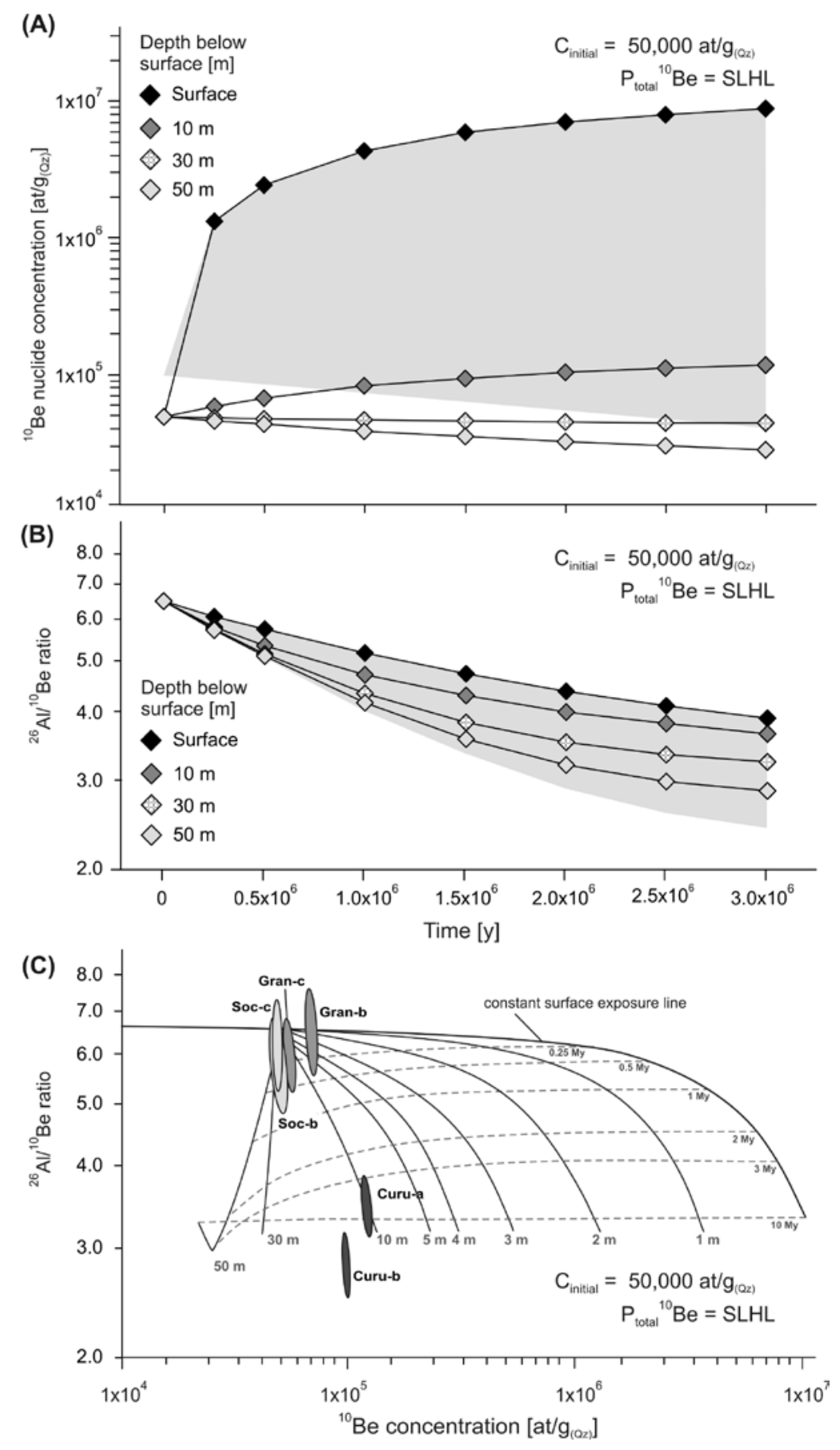

Fig. 4.(A) Evolution of the ${ }^{10} \mathrm{Be}$ nuclide concentration during ongoing irradiation. The depthdependency was calculated for SLHL nuclide production (including muons), following Schaller et al. (2002), and a sediment density of $2.0 \mathrm{~g} / \mathrm{cm}^{3}$. The initial nuclide concentration was set to $50,000 \mathrm{at} / \mathrm{g}_{(\mathrm{Qz})}$ for ${ }^{10} \mathrm{Be}$, which corresponds to an erosion rate of $\sim 0.1 \mathrm{~mm} / \mathrm{y}$. The shaded area indicates the area where the depth- and age-dependent lines would plot if the initial nuclide concentration were $100,000 \mathrm{at} / \mathrm{g}_{(\mathrm{Qz})}$ (corresponds to a slow upland erosion rate of $\sim 0.05 \mathrm{~mm} / \mathrm{y}$ ) is used, where the upper boundary of the shaded area represents the surface and the lower boundary a depth of $50 \mathrm{~m}$. (B) The corresponding evolution of the ${ }^{26} \mathrm{Al} /{ }^{10} \mathrm{Be}$ ratio with time; for the ${ }^{26} \mathrm{Al}$ nuclide concentration, the initial ${ }^{10} \mathrm{Be}$ nuclide concentration was multiplied by the surface production ratio of 6.5. (C) Same model results as in Fig. 4B but plotted in a modified erosion island plot with ${ }^{26} \mathrm{Al} /{ }^{10} \mathrm{Be}$ ratio plotted versus ${ }^{10} \mathrm{Be}$ concentration (note the scale of both axes is logarithmic). Using this plot, burial depth and burial duration can be estimated for samples that have experienced continuous irradiation during shallow floodplain burial. Grey curves give burial duration in My. Dashed grey curves are isodepth curves. The position of all curves depends on the initial concentration of the samples and on the prevailing production rate. Sample error ellipses are $1 \sigma$ level. 


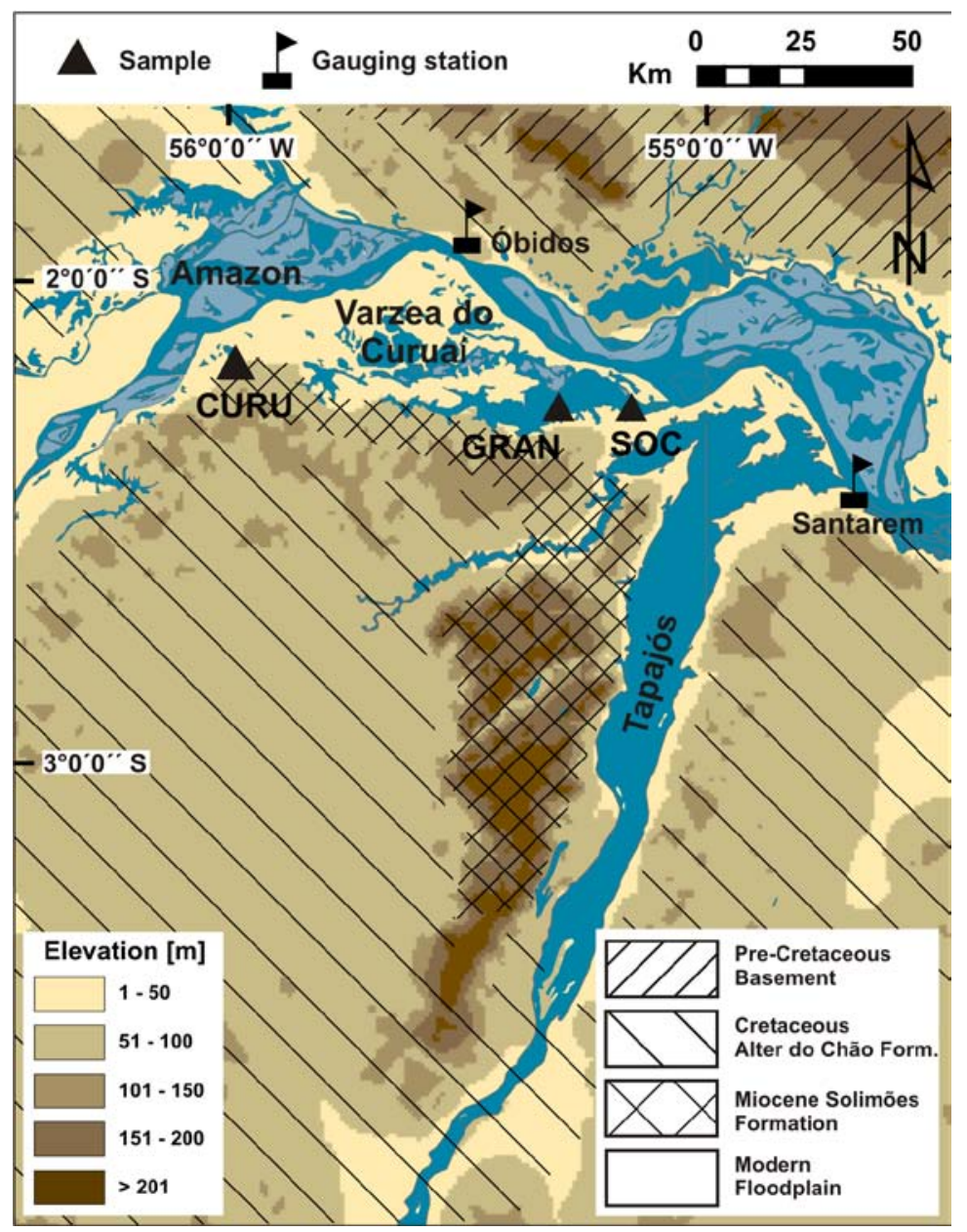

Fig. 5 Location of the "Varzea do Curuaí" near Óbidos (see inset Fig. 3). This system is taken as a representative floodplain of the central Amazon River. Geologic units have been drawn after Rossetti et al. (2005). The system is characterized by numerous black water (sample "Curu") and white water lakes (samples "Gran" and "Soc"). Sample Curu is located at the transition between Miocene and modern, Holocene floodplain. In general, the white water lakes directly receive sediment from the Amazon during rising water stage, and the black water rivers do not receive sediment from the Amazon but are connected to the system through the groundwater table. 